\title{
Elementary Analysis of Segmental Stator Flux Switching Permanent Magnet Machine
}

\author{
S. M. N. S. Othman, M. F. Omar, S. K. Rahimi, E. Sulaiman \\ Department of Electrical Power Engineering, Universiti Tun Hussein Onn Malaysia, Malaysia
}

\begin{tabular}{|c|c|}
\hline Article Info & ABSTRACT \\
\hline Article history: & \multirow{10}{*}{$\begin{array}{l}\text { Segmental structure is common especially for a rotor in electrical motor. It is } \\
\text { to reduce the cost of production, conveniently replace, and as a module } \\
\text { where the sum of electromagnetic torque produced comes from each } \\
\text { segmental stator add up together. Thus, in this paper will be focusing on the } \\
\text { elementary analysis of a segmental stator for single phase 6Slot-12Pole and } 3 \\
\text { phase } 6 \text { Slot-15Pole Switched-Flux Permanent Magnet Machine (SFPMM) as } \\
\text { the chosen design for analysis validation from coventional permanent magnet } \\
\text { flux switching machine to a new segmental stator structure of SFPMM. It } \\
\text { will be focusing on the initial design and to prove that it can be operate as a } \\
\text { flux switching machine by implement a } 2 \mathrm{D} \text { Finite Element Analysis } \\
\text { simulations such as a No-load analysis (flux linkage, cogging torque, back } \\
\text { emf) and Load-analysis (average electromagnetic torque. Elementary result } \\
\text { shows that the electromagnetic torque produce for both design are } 10.6 \mathrm{Nm} \\
\text { and } 99.95 \mathrm{Nm} \text { and proved that it can produce high torque although it does not } \\
\text { surpass the conventional SFPMM. A further research and optimization will } \\
\text { be needed to obtain a higher torque compared to conventional SFPMM. }\end{array}$} \\
\hline Received May 13, 2018 & \\
\hline Revised Jul 22, 2018 & \\
\hline Accepted Aug 8, 2018 & \\
\hline Keyword: & \\
\hline 2D FEA & \\
\hline Flux switching machine & \\
\hline Permanent magnet & \\
\hline Segmental stator & \\
\hline SFPMM & \\
\hline
\end{tabular}

Copyright $\left(C_{0} 2018\right.$ Institute of Advanced Engineering and Science. All rights reserved.

\section{Corresponding Author:}

S. M. N. S. Othman,

Department of Electrical Power Engineering,

Universiti Tun Hussein Onn Malaysia,

86400 Parit Raja, Batu Pahat, Johor, Malaysia.

Email: smnaufal@gmail.com

\section{INTRODUCTION}

Flux Switching Machine (FSM) are a type of machine that utilize flux source from permanent magnet (PM) and direct-current (DC) excitation at single or dual stator stator only. The tendency of FSM shows that it is tremendously research and develop in recent years due to their advantage of separate active and non-active part. In which it is suitable for wide range of speed, application and astounding high flux density $[1,2]$. Based on this advantages, researchers are applying the principle of flux switching to design an electric machine solely based on PM, DC excitation, or both such as hybrid FSM [3].

Hence, an electromechanical framework intended for such applications must be stable and dependable, where the defect parts can be effectively and promptly recover. From the literature review, Switch Reluctance Motor (SRM) and permanent magnet (PM) machine is the two highlighted research in the electrical machine for fault tolerance study. As you may know, it is naturally fault tolerant in SRM where each phase of an SRM can be considered as single and separate due to non-shared coupling. Whereby, a fault in one phase winding will have no effect towards other phase and the machine can operate solely dependent on the faultless phases [4]. While a PM machines with high phase number are designed for fault-tolerant operation. Since it have a greater torque density than SRMs, their optimal design structure is affected in order to improve the fault tolerance [5].

Besides, recent year shows that a PM machines efficient development in drive system and FEA design software attract more researcher attention. Specifically, a Switched Flux (SF) PM machines, as shown 
in Figure 1 (a), have special interest due to their high torque density, high efficiency and rigid rotor assembly [6,7]. In addition, SFPM machines have indicate improvement in comparison to a synchronous machine in high speed range generator, due to compelling part to relief of PM demagnetization in high-speed operation. Moreover, SFPM machine have been redesigned to obtain a sufficient torque density that are better than most doubly salient PM machines [8].

Thereby, in this paper will discussed on a segmental stator structure proposed for Switched-Flux Permanent Magnet Machine, (SFPMM). With its good magnetic separation and the possibility of the independent feeding for each segmental stator core gives the advantage of high fault tolerance together with the accessible to maintain and directly performed a replacement of the damaged parts. Furthermore, in this paper will shows that the proposed design are able to produce a high torque, acceptable back electromagnetive force and cogging torque [9].

\section{CONCEPT OF SEGMENTAL STATOR SF-PMM}

Figure 1 (b) illustrate the proposed 1-phase segmental stator 6S-12P and Figure 1 (c) illustrates the 3-phase segmental stator 6S-15P. From the propose design, the concept of segmental stator of SFPMM are made up of discontinued section or segments, thus creating the segments. Furthermore, the stator structure is in a $\mathrm{C}$ core shape where it is alternately arranged together between them a PM with the both end of each segmental stator only occupy a half $\mathrm{C}$ core shape stator.

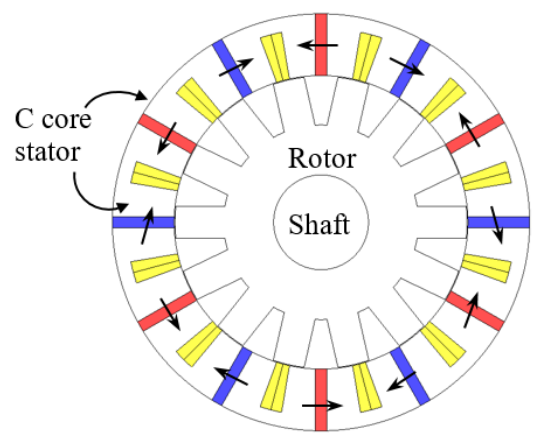

(a)

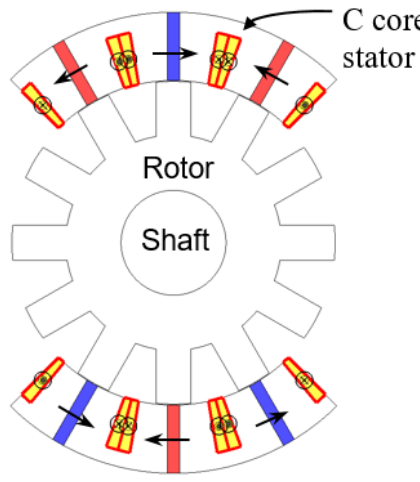

(b)

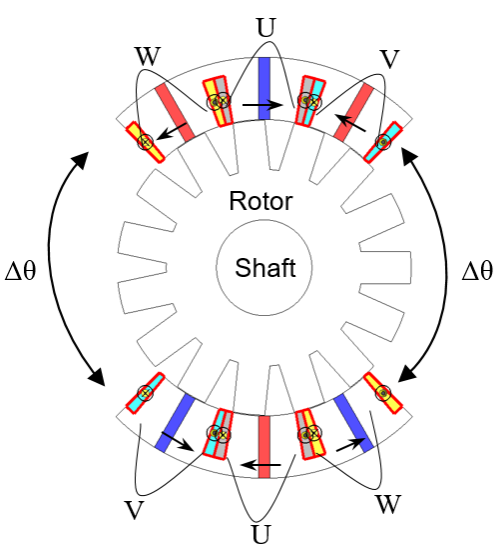

(c)

Figure 1. (a) 3-phase conventional C core stator SFPMM and (b) 1-phase 12Slot-14Pole (c) 3-phase 12Slot-15Pole segmental stator SFPM machines

Figure 2 illustrate the proposed segmental stator SF-PMM with the PM direction and armature copper winding respectively. This electric motor applies segmental structure for the stator with uniform airgap between them, and $180^{\circ}$ apart between two segmental stator structure, as illustrates in Figure 1 above. Hence, when the respective phase is excited, the flux line of the propose design is short and form a small loop at each $\mathrm{C}$ core stator. In conjunction with the segmental stator, it is not magnetically couple and separate by a non-magnetic material. The angular shift $\Delta \theta$ between two segmental stator respects the following relations:

$$
\Delta \theta=\frac{2 \Pi}{q N_{c}}
$$

Where $q$ is the phase number and $N_{c}$ are the stator core for each phase $\left(\mathrm{N}_{\mathrm{c}}=2\right)$. In contrary to the flux distribution, Fig. 3 shows that the proposed design encounters a flux repeal and flux exposure as highlighted in red circles. The objective of flux distribution is to distribute the flux uniformly, control the flow of flux, and determine the location of flux saturation in the machine and to fully utilize the flux in the proposed design. Meanwhile, a design optimization will be performed at the various machine parameters to improve the flux linkage especially at the flux path. 


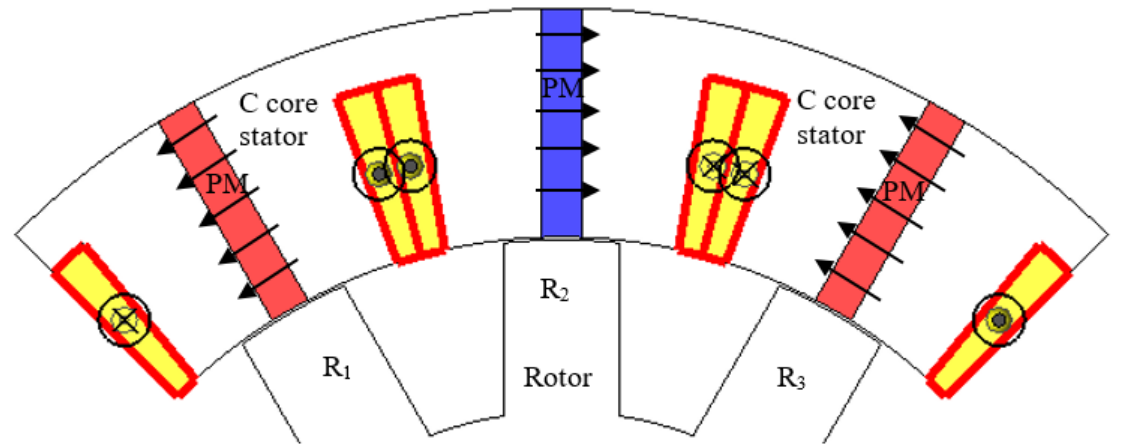

Figure 2. Initial design of 1 phase segmental stator SFPMM

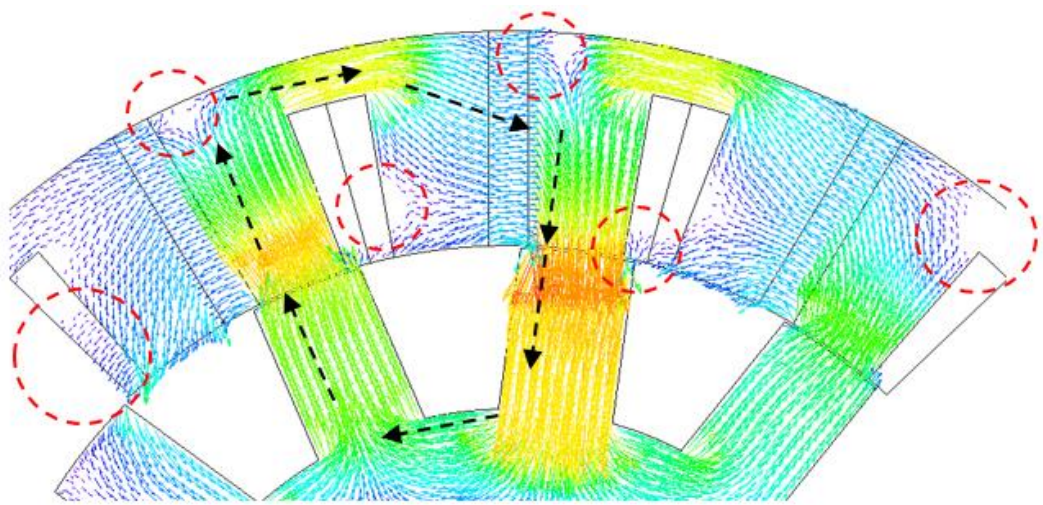

Figure 3. Flux distribution of 1 phase 6S-12P SFPMM

\section{RESULTS AND ANALYSIS}

Mainly this paper will be focusing on the design study and performance analysis of the single phase, 6Slot-12Pole and three phase 6Slot-15Pole segmental stator SFPMM. The segmental stator SFPMMs geometry parameters and specification are listed in Table I. From the structure, it is clear that both design is having 12 stator teeth but different rotor pole number. Furthermore, current density of armature coil, Ja proposed machine can be determined by Equation 2 .

$$
J_{a}=\frac{I_{a} N_{a}}{\alpha S_{a}}
$$

where $I_{a}$ is there current injection, $N_{a}$ is number of armature coil winding, $\alpha$ is the filling factor and $S_{a}$ is the area of armature slot. Commonly, the relation between a mechanical rotation frequency and the electrical frequency for both machines can be expressed as in Equation 3.

$$
f_{e}=N_{r} f_{m}
$$

Where $f_{e}$ is the electrical frequency, $f_{m}$ is the mechanical rotation frequency and $N_{r}$ is the rotor pole number, respectively. The performances of each designs are divided by two parts, which are no-load and load condition. Workflow for analysis in no-load and load condition is summarised as in Figure 4. The performances are compared by considering various characteristics such as flux linkages, back emf, and cogging torque. The main reason is to determine the best results in high flux linkages, less cogging torque, low phase back EMF and high average torque. Table 1 shows parameter specifications of 1 phase and 3 phase SFPMM. 
Table 1. Parameter Specifications of 1 Phase and 3 Phase SFPMM

\begin{tabular}{ccc}
\hline Parameters & 1 Phase SFPMM & 3 Phase SFPMM \\
\hline Rotor pole number & 12 & 15 \\
Stator outer radius & $132 \mathrm{~mm}$ & $132 \mathrm{~mm}$ \\
Rotor outer radius & $92.4 \mathrm{~mm}$ & $92.4 \mathrm{~mm}$ \\
Stach length & $70 \mathrm{~mm}$ & $70 \mathrm{~mm}$ \\
Air gap & $0.5 \mathrm{~mm}$ & $0.5 \mathrm{~mm}$ \\
PM weight & $0.868 \mathrm{~kg}$ & $0.868 \mathrm{~kg}$ \\
Armature turns & $7 \mathrm{turns}$ & 7 turns \\
Armature slot area & $168 \mathrm{~mm} 2$ & $168 \mathrm{~mm} 2$ \\
Stator pole width & $17 \mathrm{~mm}$ & $17 \mathrm{~mm}$ \\
Rotor pole width & $20 \mathrm{~mm}$ & $16 \mathrm{~mm}$ \\
\hline
\end{tabular}

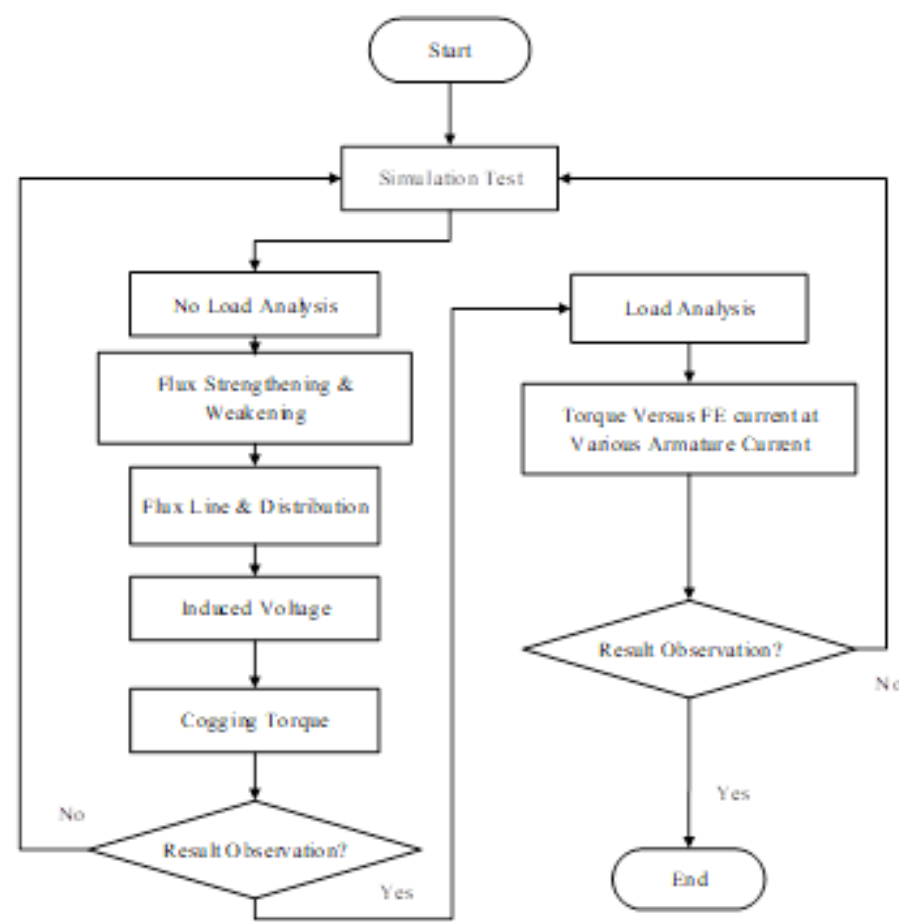

Figure 4. Performance analysis of segmental stator SFPM machine based on FEA

While in load condition, armature coil is injected with armature current density set to 5 Arms $/ \mathrm{mm} 2$, 10 Arms $/ \mathrm{mm} 2,15$ Arms $/ \mathrm{mm} 2,20$ Arms $/ \mathrm{mm} 2,25$ Arms $/ \mathrm{mm} 2$, and a maximum current density of 30 Arms $/ \mathrm{mm} 2$. In load analysis, the value of input current of armature coil, Ja will be supplied to the circuit, which have been calculated while considering the armature slot area and number of armature coil turn when $\mathrm{Ja}$ are at maximum current density of $30 \mathrm{Arms} / \mathrm{mm} 2$. The flux distribution of the initial design in load condition will be investigated where armature current is set to maximum current density of 30 Arms $/ \mathrm{mm} 2$, respectively.

\section{ELECTROMAGNETIC PERFORMANCE BASED ON 2-D FEA}

This section discussed on the electromagnetic performance of the studied topologies. The results aim to reveal the characteristic of electromagnetic based on the phase flux linkage, Back-EMF, cogging torque and electromagnetic torque.

\subsection{Magnetic Flux Linkage for Single Phase 6Slot-12Pole and Three Phase 6Slot-15Pole}

A key factor for all developed FSM models is the phase flux linkage calculation, which creates significant challenge, since the stator has salient poles and the iron core saturation has a significant influence on the motor's operation. Previous research works were published in the last decade in this domain, as which introduce analytical models to calculate the flux linkage, which develop models based on magnetic equivalent circuits, or the analytical model is created using FEM analysis results ]. 
The analysis of field distribution in No-Load based on 2D FEA for the design is illustrated in Figure 5. From the figure, it portrays the flux pattern due to magnetomotive force, MMF of PM only. Meanwhile, it is approximately $90 \%$ of the flux flow from the PM in the C core stator and the rest of flux flows concentrated at the rotor periphery due to flux strengthening and lead to a higher torque. As for the graph in Figure 6 it is obvious that 1-phase 6S-12P has high flux linkage amplitude, $0.0357 \mathrm{~Wb}$ compare to 3 phase $6 \mathrm{~S}-15 \mathrm{P}$ topologies, $0.017 \mathrm{~Wb}$. This means that the 1 -phase $6 \mathrm{~S}-12 \mathrm{P}$ segmental stator design has a higher ability to give high torque and power. While the 3-phase $6 \mathrm{~S}-15 \mathrm{P}$ segmental stator only giving a less flux linkage due to excess leakage and cancelling of flux occurs of the rotor pole. It is expected that it is caused by the rotor pole number configuration and will further investigate in the future.

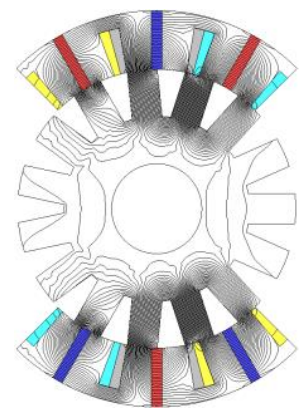

(a)

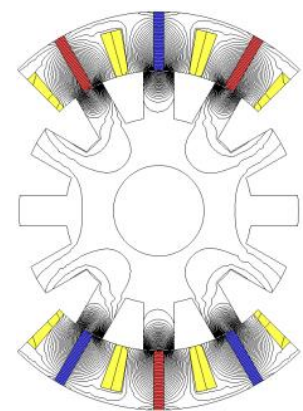

(b)

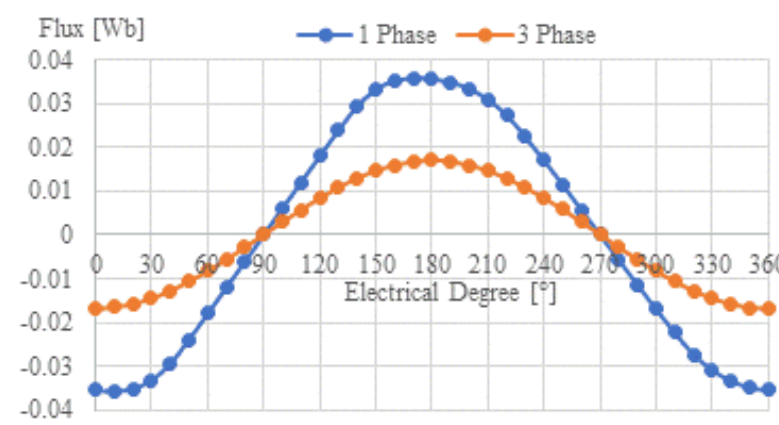

Figure 6. U-phase flux linkage of 1-phase 6S-12P and 3-
phase $6 \mathrm{~S}-15 \mathrm{P}$

Figure 6. U-phase flux linkage of 1 -phase $6 \mathrm{~S}-12 \mathrm{P}$ and $3-$
phase $6 \mathrm{~S}-15 \mathrm{P}$
Figure 5. Flux path of the (a) 3-Phase (b) 1-Phase segmental stator SFPMM design at no load condition, PM only

\subsection{Cogging Torque Analysis}

The proposed segmental stator design reveal a high cogging torque for $6 \mathrm{~S}-15 \mathrm{P}$ and $6 \mathrm{~S}-12 \mathrm{P}$ design as illustrated in Figure 7. Cogging torque is known as detent or no-current torque that generate noise and vibration in machine operation. Whereby, the cogging torque of both design investigation for one electrical cycle is illustrated in Figure 7. It is concerned that the result of high cogging torque comes from the angular space between segmental stator. In future, an optimization towards the design geometry structure will be made to reduce the cogging torque peak to peak value and concurrently improve the electromagnetic torque performance.

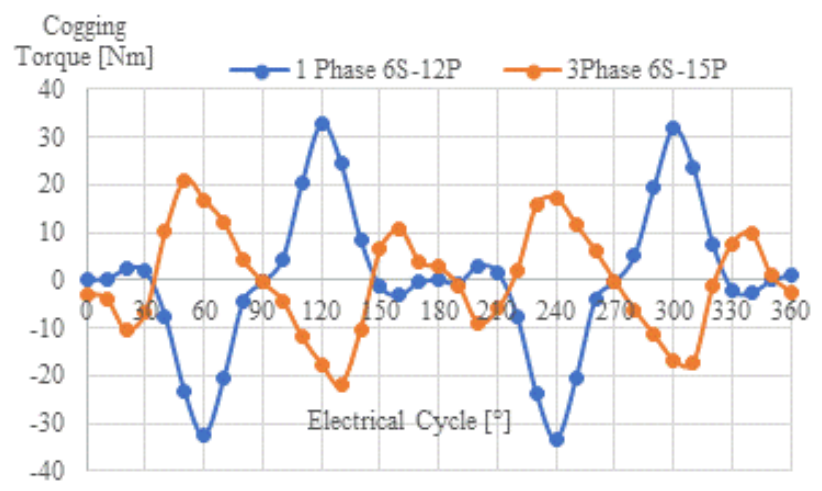

Figure 7. U-phase flux linkage of 1-phase 6S-12P and 3-phase 6S-15P

\subsection{Phase Back EMF}

From the Figure 8, it is shown that the reaction of back-Emf are plotted and that the phase BackEMF of both design is precise towards the fundamental sinusoidal, however the single-phase machine produces a high fundamental amplitude of $94 \mathrm{~V}$ followed by $31.8 \mathrm{~V}$ of the three phases respectively. 
Furthermore, the three phase SFPMM exhibits the lowest Total Harmonic Distortion, THD of $2.0 \%$ whilst the 1 phase machine exhibits a higher THD of $5.0 \%$. Hence, from the Eq. (4) below, the phase back EMF, E is directly proportional to the constant value, $k$ multiplies with the speed of rotation, $\omega$ and flux linkage $(\phi)$.

$$
E=k \phi \omega
$$

\subsection{Electromagnetic Torque at Various Armature Current Densities, $\mathbf{J}_{\mathrm{a}}$}

The electromagnetic torque output at distinct armature current densities, $\mathrm{J}_{\mathrm{a}}$ conditions are plotted in Figure 9. The plots clearly demonstrate that the most elevated torque accomplished is $10.6 \mathrm{Nm}$ for 1 phase $6 \mathrm{~S}-12 \mathrm{P}$ and $99.95 \mathrm{Nm}$ for 3 phase $6 \mathrm{~S}-15 \mathrm{P}$ SFPMM when $\mathrm{J}_{\mathrm{a}}$ are heighten to $30 \mathrm{~A}_{\mathrm{rms}} / \mathrm{mm}^{2}$. From the figure, the torque attributes are expanded with the expansion of $\mathrm{J}_{\mathrm{a}}$. At small armature current density, $\mathrm{J}_{\mathrm{a}}$, the torque continues to gain until the ideal torque is accomplished. It shows that the electromagnetic torque difference are about ten times of the 1 phase segmental stator SFPMM.

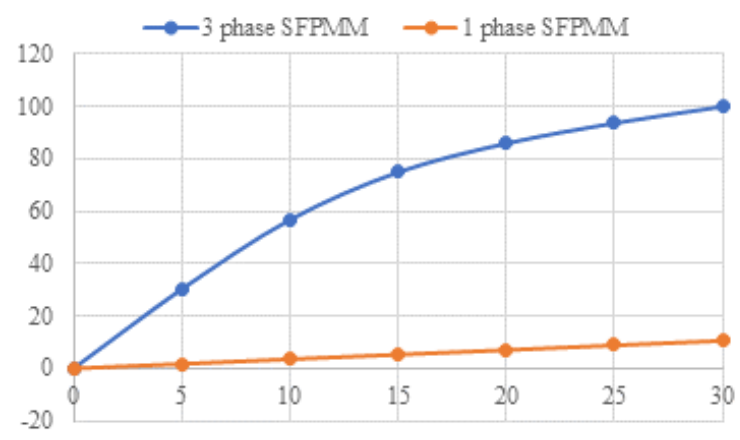

Figure 9. Average electromagnetic torque of 1 phase $6 \mathrm{~S}-12 \mathrm{P}$ and 3 phase $12 \mathrm{~S}-15 \mathrm{P}$ of SFPMM

\section{CONCLUSION}

It is clear to conclude that a preliminary design and elementary analysis of a new segmental stator single phase 6Slot-12Pole SFPMM and 6Slot-15Pole SFPMM are presented. The novelty of the proposed design is segmental stator structure, which improve the flux linkage, improve the fault tolerant by making it segmental, and provide credibility to uniformly isolate each segmental stator but give a maximum total ouput torque. Although the preliminary design had insufficient electromagnetic torque, a further analysis such as power output and efficiency will be done in the future. Therefore, a design optimization approach will be necessary for this research to enhance the output torque, power, and overall efficiency relativity to current preliminary design. The interest of this geometry structure is elementary, insure sufficient flux linkage and high electromagnetic torque at base speed. Therefore, it is prudent to conclude that the 2D FEA results present in this paper are acceptable.

\section{ACKNOWLEDGEMENTS}

This paper was sponsored by the (Geran FRGS, Vot 1651) from the Ministry of Higher Education, MOHE of Malaysia and University Tun Hussein Onn Malaysia (UTHM), Batu Pahat.

\section{REFERENCES}

[1] 1. Othman SMNS, Ahmad MZ, Rahim JA, Bahrim FS, Sulaiman E. Design Improvement of Three Phase 12Slot14Pole Outer Rotor Field Excitation Flux Switching Motor. 2017;8(1):239-47.

[2] 2. Sulaiman E, Kosaka T, Matsui N. Design and analysis of high-power/high-torque density dual excitation switched-flux machine for traction drive in HEVs. Renew Sustain Energy Rev [Internet]. Elsevier; 2014;34:51724. Available from: http://dx.doi.org/10.1016/j.rser.2014.03.030

[3] 3. Khan F, Sulaiman E, Ahmad MZ. Review of Switched Flux Wound-Field Machines Technology. IETE Tech Rev (Institution Electron Telecommun Eng India). 2017;34(4):343-52.

[4] 4. Szabo L, Ruba M. Segmental stator switched reluctance machine for safety-critical applications. IEEE Trans Ind Appl. 2012;48(6):2223-9. 
[5] 5. Jack a. G, Mecrow BC, Haylock J. A comparative study of permanent magnet and switched reluctancelnmotors for high performance fault tolerant applications. IAS '95 Conf Rec 1995 IEEE Ind Appl Conf Thirtieth IAS Annu Meet. 1995;1(4):889-95.

[6] 6. Zhu Z. Switched flux permanent magnet machines - Innovation continues. Electr Mach Syst (ICEMS), 2011 ... [Internet]. 2011;(c). Available from: http://ieeexplore.ieee.org/xpls/abs_all.jsp?arnumber=6073317

[7] 7. Chen JT, Zhu ZQ. Winding configurations and optimal stator and rotor pole combination of flux-switching PM brushless AC machines. IEEE Trans Energy Convers. 2010;25:293-302.

[8] 8. Machines FP, Mcfarland JD, Jahns TM, El-refaie AM. Analysis of the Torque Production Mechanism for. 2015;51(4):3041-9.

[9] 9. Zhu ZQ, Chen JT. Advanced flux-switching permanent magnet brushless machines. IEEE Trans Magn. 2010;46(6):1447-53.

[10] 10. Zhu ZQ, Liu Y. Analysis of Air-gap Field Modulation and Magnetic Gearing Effect in Fractional Slot Concentrated Winding Permanent Magnet Synchronous Machines. IEEE Trans Ind Electron [Internet]. 2017;51(5):1-1. Available from: http://ieeexplore.ieee.org/document/8064199/

\section{BIOGRAPHIES OF AUTHORS}
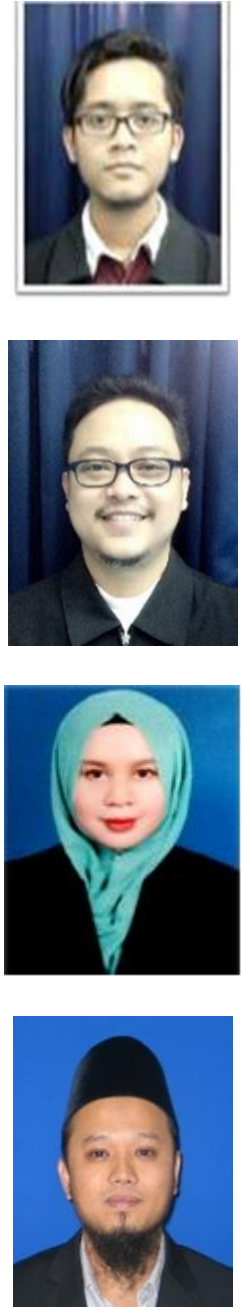

Syed Muhammad Naufal Syed Othman was born on 26th of December, 1990 in Johor Bahru, Johor, Malaysia who is currently a PhD scholar at Universiti Tun Hussein Onn Malaysia (UTHM), Johor. Obtained a Bachelor degree and Master degree (Research) in Faculty of Electrical Engineering and Research Centre for Applied Electromagnetics (EMC) at University Tun Hussein Onn Malaysia in 2013 and 2016. Research interest in electric machine design, niche in flux switching machine for direct drive application.

Mohd. Fairoz Omar was born in Johor, Malaysia, on May, 12, 1986. He received Diploma in Electric and Electronic Engineering from Politeknik Ibrahim Sultan in 2008. Since October 2008, he has been working under Asian Geos (M) Sdn. Bhd as Technician. He received his B.E Degree in Electronic Engineering and M.E Degree in Electrical Engineering from University Tun Hussein Onn Malaysia, in 2014 and 2016, respectively. Currently, he is Ph.D. Degree at Department of Electrical Power Engineering, University Tun Hussein Onn Malaysia. His research interests include permanent magnet flux switching machines (PMFSMs) for electric buses.

Siti Khalidah Rahimi was born in Kelantan, Malaysia, on October 17, 1990. She received her B.E, M.E degrees in Electrical Engineering from Universiti Tun Hussein Onn Malaysia (UTHM) in 2013 and 2016. Curenttly, she is PhD candidate at Universiti Tun Hussein Onn Malaysia (UTHM). Her research interest is electric machine design especially in flux switching machine for Hybrid Electric Vehicles.

Erwan Sulaiman who is currently serving as a senior lecturer at University Tun Hussein Onn Malaysia (UTHM) was born on August 31, 1978 in Johor, Malaysia. He gained his Bachelor's degree and Master degrees in Electrical Engineering from University of Malaya in 2001 and 2004. He has been with UTHM from December 2004 and obtained Doctor Degree in Electrical Engineering from Nagoya Institute of Technology (NIT), Japan in 2012. His research interests include design optimizations of HEFSM, WFFSM, in particular, for HEV drive applications. 